\title{
Experimental Investigations on Strength Characteristics of High Performance Concrete Using Silica Fume and Superplasticizer
}

\author{
Dr. K. Perumal ${ }^{1}$, S. Senthilkumar ${ }^{2}$, K. Sekar ${ }^{3}$ \\ ${ }^{1}$ Head of Department, ${ }^{2}$ Lecturer (Senior Grade), ${ }^{3}$ Associate Professor, \\ ${ }^{1,2}$ Dept of Civil Engineering, Sri Ramakrishna Mission Vidyalaya Polytechnic College, Tamil Nadu, India \\ ${ }^{3}$ Dept of Civil Engineering, Ranganathan Engineering College, Coimbatore, Tamil Nadu, India
}

\begin{abstract}
For several decades, concrete has been the most widely used construction material. Though conventional concrete $(\mathrm{CC})$ performs very well under normal conditions, in special situations a very high compressive strength of concrete is necessary together with sustainability to aggressive environments. Hence, higher compressive strength of range 60-140 $\mathrm{MPa}$ is essential. The concrete mixes so far were designed only for strength and workability requirements. For the performance of long satisfactory life, the designed mixes should be checked and proved for their durability properties such as low permeability, high corrosion resistance, freezing and thawing resistance, fire existence etc. This necessitates a detailed study on High performance concrete (HPC). This paper formulates a simplified mix design procedure for HPC by combining BIS and ACI code methods of mix design and available literatures on HPC. Based on the above procedure M80 and M100 mixes are arrived at. These HPC mixes are tested experimentally for compression, split tension, flexure and workability. The performance of the designed mixes is very good and the results are reported in this paper.
\end{abstract}

Keyword: low permeability, resistance, fire existence, $H P C$

\section{INTRODUCTION}

HPC is a construction material which is being used in increasing volumes in recent years due to its longterm performance and better rheological, mechanical and durability properties than CC. HPC possesses invariably high strength, reasonable workability and negligible permeability. Compared to $\mathrm{CC}$, preparation of HPC requires lower water-binder $(w / b)$ ratio and higher cement content. The durability properties of concrete are given importance, which makes High Strength Concrete (HSC) into HPC. HSC refers to concretes of grade above M60. High strength and better durability properties become reality for $\mathrm{CC}$ by reducing porosity, in homogeneity, micro cracks in concrete and the transition zone. This is how HPC is evolved.

Incorporation of mineral admixtures like Silica Fume (SF), Fly ash, Granulated ground blast furnace slag, Rice husk ash act as pozzolanic materials as well as micro fillers, thereby the microstructure of hardened concrete becomes denser and improves the strength and durability properties. Addition of chemical admixtures such as super plasticizer improves the properties of plastic concrete with regard to workability, segregation etc.

The HPC permits use of reduced sizes of structural members, increased building height in congested areas and early removal of formwork. The use of HPC in pre-stressed concrete construction makes greater span-depth ratio, early transfer of pre-stress and early application of service loads. Low permeability characteristic of HP Creduces risk of corrosion of steel and attack of aggressive chemicals. This permits the use of HPC in marine/offshore structures, nuclear power plants, bridges and places of extreme and adverse climatic conditions. Eventually, HPC reduces maintenance and repair costs.

\section{MECHANISM OF HPC}

According to Nevillie "HPC is a concrete to fulfill specified purpose and no special mystery about it, no unusual ingredients or special equipment's have to be 
used. But to understand the behavior of concrete and will, to produce a concrete mix within closely controlled tolerances". Concrete is a three-phase composite material, the first two phases being aggregates and bulk hydrated cement paste (hcp) and the third being the "transition zone". The transition zone is the interfacial region between the aggregate particles and the bulk "hcp". It is the weakest link and if this is strengthened, then the strength and impermeability (durability characteristics) of concrete are improved to a greater extent. This is made possible by reducing w/b ratio and use of SF. SF improves the above properties by pozzolanic action and by reactive filler effect. SF contains a very high percentage of amorphous silicon dioxide which reacts with large quantity of $\mathrm{Ca}(\mathrm{OH})_{2}$ produced during hydration of cement to form calcium-silicate-hydrate (C-S-H) gel. This gives strength as well as improves impermeability. This is known as pozzolanic action (chemical mechanism). Another action, a physical mechanism called "filler effect" in which the small spherical shaped SF particles disperse in the presence of a super plasticizer to fill the voids between cement particles and accelerates the hydration of $\mathrm{C}_{3} \mathrm{~S}$, since $\mathrm{SF}$ is fine reactive filler. These results in well packed concrete mix. Due to pozzolanic action between SF and $\mathrm{Ca}(\mathrm{OH})_{2}$, the larger size crystals of $\mathrm{CA}(\mathrm{OH})_{2}$ converts to crystal of C-S-H gel which is dense, leading to reduction of pore size. This effect along with the improved particle distribution results in reduction of the thickness of transition zone and leads to densely packed stronger and less permeable concrete.

\section{SIGNIFICANCE AND OBJECTIVES}

The objectives of the present investigation are to develop a simplified mix design procedure, specially for HPC by varying the percentage replacement of cement by SF $(0-15 \%)$ at a constant dosage of super plasticizer, based on BIS \& ACI code methods of mix design procedure and available literatures on HPC. Investigations were carried out on the above procedure to produce HPC mixes for M80 and M100 grades using $12.5 \mathrm{~mm}$ maximum size of aggregates to ascertain the workability and the mechanical properties of the designed mixes and to find an optimum cement replacement by SF.

Hence in the present investigation more emphasis is given to study the HPC using SF and super plasticizer so as to achieve better concrete composite and also to encourage the increased use of SF to maintain ecology.

\section{EXPERIMENTAL PROGRAMME}

Experimental investigations have been carried out on the HPC specimens to ascertain the workability and strength related properties such as compressive strength, split tensile strength, flexural strength and Elastic modulus of the designed trial mixes and also Non- Destructive Test (NDT) - Ultrasonic Pulse Velocity (UPV) has been carried out to check the quality of concrete.

\subsection{Materials used}

1. Ordinary Portland Cement (OPC), 53 Grade conforming to BIS: $12269-1987$.

2. Silica Fume as mineral admixture in dry densified form obtained from ELKEM INDIA (P) LTD., Mumbai conforming to ASTM C - 1240.

3. Super plasticizer (chemical admixture) based on Sulphonated Naphthalene Formaldehyde condensate - CONPLAST SP 430 conforming to BIS: 9103 - 1999 and ASTM C-494.

4. Locally available quarried and crushed granite stones confirming to graded aggregate of nominal size $12.5 \mathrm{~mm}$ as per table 2 of BIS: $383-1970$ with specific gravity 2.82 and fineness modulus 6.73 as Coarse aggregates (CA).

5. 5. Locally available Karur river sand conforming to Grading zone II of table 4 of BIS: 383-1970 with specific gravity 2.60 and fineness modulus 2.96 as fine aggregates (FA).

6. Water: Drinking water supplied to Coimbatore city from Siruvani dam for concreting and curing.

\subsection{Mix Design for HPC}

Since there is no specific method of mix design found suitable for HPC, a simplified mix design procedure is formulated by combining the BIS method, ACI methods for concrete mix design and the available literatures on HPC using SF.

\section{Formulation of mix design procedure Target mean strength}

The target mean strength $\left(\overline{f_{c k}}\right)$ is calculated as follows:

$\left(\mathrm{f}_{\mathrm{ck}}\right)=\mathrm{f}_{\mathrm{ck}}+(\mathrm{t} \times \mathrm{S})$ with usual BIS notations. When adequate data are not available to establish ' $\mathrm{S}$ ', the ( $f_{\text {ck }}$ ) value can be determined from the following table 1 as given by ACI Report 318 . 
International Journal of Trend in Scientific Research and Development (IJTSRD) ISSN: 2456-6470

Table 1: Target mean strength when data are not available to establish a standard deviation

\begin{tabular}{|c|c|}
\hline $\begin{array}{c}\text { Specified characteristic } \\
\text { compressive strength, } \\
\text { fck (MPa) }\end{array}$ & $\begin{array}{c}\text { Target mean } \\
\text { compressive strength, } \\
\mathrm{fck}_{\mathrm{ck}}(\mathrm{MPa})\end{array}$ \\
\hline Less than 20.5 & $\mathrm{f}_{\mathrm{ck}}+6.9$ \\
$20.5-34.5$ & $\mathrm{f}_{\mathrm{ck}}+8.3$ \\
More than 34.5 & $\mathrm{f}_{\mathrm{ck}}+9.7$ \\
\hline
\end{tabular}

Selection of maximum size of coarse aggregate (CA)

The maximum size of the coarse aggregate is selected from the following table 2 as given by ACI Report 211.4R.93.

Table 2: Maximum size of coarse aggregate

\begin{tabular}{l|l} 
Required Concrete & Maximum aggregate
\end{tabular} Strength (MPa) size $(\mathrm{mm})$

Less than 62

Greater than or equal to 62
$20-25$

$10-12.5$

\section{Estimation of free water content}

The water content to obtain the desired workability depends upon the amount of water and amount of super plasticizer and its characteristics. However, the saturation point of the super plasticizer is known, and then the water dosage is obtained from the following table 3. If the saturation point is not known, it is suggested that a water content of 145 litres $/ \mathrm{m}^{3}$ shall be taken to start with.

Table 3: Determination of the minimum water dosage

\begin{tabular}{|c|c|c|c|c|c|}
\hline $\begin{array}{c}\text { Saturation } \\
\text { point }(\%)\end{array}$ & 0.6 & 0.8 & 1.0 & 1.2 & 1.4 \\
\hline $\begin{array}{c}\text { Water } \\
\text { dosage } \\
\left(1 / \mathrm{m}^{3}\right)\end{array}$ & $\begin{array}{c}120 \\
\text { to125 }\end{array}$ & $\begin{array}{c}125 \\
\text { to } 135\end{array}$ & $\begin{array}{c}135 \\
\text { to } 145\end{array}$ & $\begin{array}{c}145 \\
\text { to } 155\end{array}$ & $\begin{array}{c}155 \\
\text { to } 165\end{array}$ \\
\hline
\end{tabular}

\section{Super plasticizer dosage}

The super plasticizer dosage is obtained from the dosage at the saturation point. If the saturation point is not known, it is suggested that a trial dosage of $1.0 \%$ shall be taken to start with.

\section{Estimation of air content}

The air content (approximate amount of entrapped air) to be expected in HPC is obtained from the following table 4 as given by ACI Report 211.4R.93 for the maximum size of CA used. However, it is suggested that an initial estimate of entrapped air content shall

be taken as $1.5 \%$ or less since it is HPC, and then adjusting it on the basis of the result obtained with the trial mix.

\section{Table 4 Approximate entrapped air content}

\begin{tabular}{|c|c|}
$\begin{array}{c}\text { Nominal maximum } \\
\text { size of coarse } \\
\text { aggregate }(\mathrm{mm})\end{array}$ & $\begin{array}{c}\text { Entrapped air, as } \\
\text { percent of volume of } \\
\text { concrete }\end{array}$ \\
\hline 10 & 2.5 \\
12.5 & 2.0 \\
20 & 1.5 \\
25 & 1.0 \\
\hline
\end{tabular}

Selection of coarse aggregate (CA) content

The coarse aggregate content is obtained from the following table 5 as a function of the typical particle shape. If there is any doubt about the shape of the CA or if its shape is not known, it is suggested that a CA content of $1000 \mathrm{~kg} / \mathrm{m}^{3}$ of concrete shall be taken to start with. The CA so selected should satisfy the requirements of grading and other requirements of BIS: $383-1970$.

\section{Table 5 Coarse aggregate content}

\section{Selection of water - binder (w/b) ratio}

The water-binder ratio for the target mean compressive strength is chosen from figure 1 , the proposed $\mathrm{w} / \mathrm{b}$ ratio Vs compressive strength relationship. The $\mathrm{w} / \mathrm{b}$ ratio so chosen is checked against the limiting w/c ratio for the requirements of durability as per table 5 of BIS: $456-2000$, and the lower of the two values is adopted.

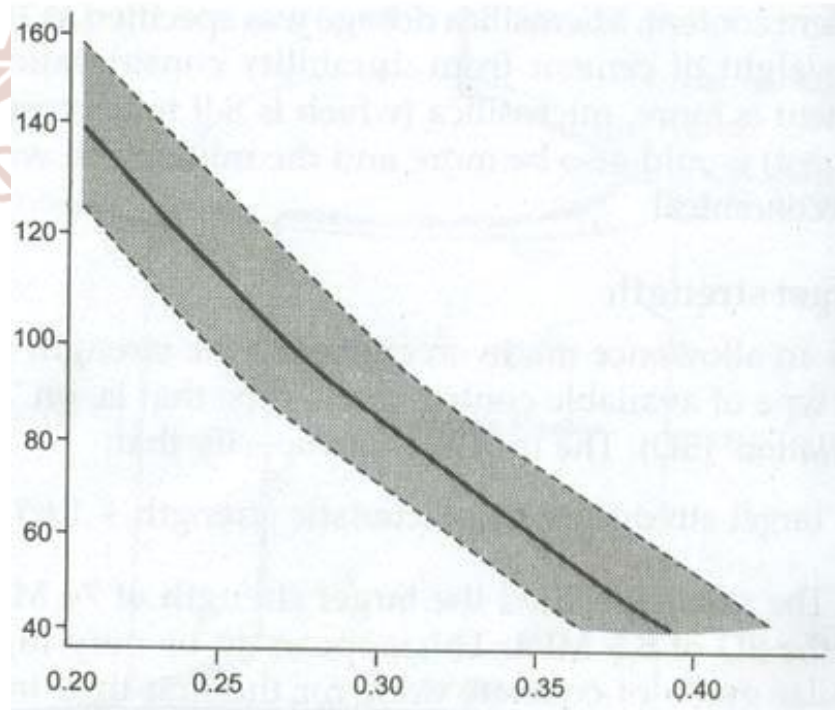

Fig.1 Proposed w/b ratio Vs compressive strength relationship Calculation of binder contents 
The binder or cementitious contents per $\mathrm{m}^{3}$ of concrete is calculated from the $w / b$ ratio and the quantity of water content per $\mathrm{m}^{3}$ of concrete. Assuming the percentage replacement of cement by SF $(0-15 \%)$, the SF content is obtained from the total binder contents. The remaining binder content is composed of cement. The cement content so calculated is checked against the minimum cement content for the requirements of durability as per table 5 and 6 of BIS: $456-2000$ and the greater of the two values is adopted.

\section{Super plasticizer content:}

The mass of solids in the super plasticizer $\left(\mathrm{M}_{\mathrm{sol}}\right)$ in $\mathrm{kg}$, the volume of liquid super plasticizer $\left(\mathrm{V}_{\text {liq }}\right)$, the volume of water in the liquid super plasticizer $\left(\mathrm{V}_{\mathrm{w}}\right)$ and the volume of solids in the liquid super plasticizer $\left(\mathrm{V}_{\mathrm{sol}}\right)$ are calculated from the following equations:

$$
\begin{aligned}
& \mathrm{M}_{\text {sol }}=\mathrm{C} \times \frac{\mathrm{d}}{100} \\
& \mathrm{~V}_{\text {liq }}=\frac{\mathrm{M}_{\text {sol }} \times 100}{\mathrm{~s} \times \mathrm{S}_{\mathrm{s}}} \\
& \mathrm{V}_{\mathrm{w}}=\mathrm{V}_{\text {liq }} \times \mathrm{S}_{\mathrm{s}}\left[\frac{100-\mathrm{s}}{100}\right] \\
& \mathrm{V}_{\text {sol }}=\mathrm{V}_{\text {liq }}-\mathrm{V}_{\mathrm{w}}
\end{aligned}
$$

Where

$\mathrm{C}=$ mass of the cementitious materials $(\mathrm{kg})$

$\mathrm{d}=$ super plasticizer dosage expressed as the \% of its solid content

$\mathrm{s}=$ total solid content of the super plasticizer in percent, and

$\mathrm{S}_{\mathrm{s}}=$ specific gravity of the liquid super plasticizer

\section{Estimation of fine aggregate (FA) content}

The absolute volume of FA is obtained from the following equation:

$$
\mathrm{V}_{\mathrm{fa}}=1000-\left[\mathrm{V}_{\mathrm{w}}+\frac{\mathrm{M}_{\mathrm{c}}}{\mathrm{S}_{\mathrm{c}}}+\frac{\mathrm{M}_{\mathrm{sf}}}{\mathrm{S}_{\mathrm{sf}}}+\frac{\mathrm{M}_{\mathrm{ca}}}{\mathrm{S}_{\mathrm{ca}}}+\mathrm{V}_{\mathrm{sol}}+\mathrm{V}_{\mathrm{ea}}\right]
$$

\section{Where}

$\mathrm{V}_{\mathrm{fa}}=$ absolute volume of FA in litres per $\mathrm{m}^{3}$ of concrete

$\mathrm{V}_{\mathrm{w}}=$ volume of water (litres) per $\mathrm{m}^{3}$ of concrete

$\mathrm{M}_{\mathrm{c}}=$ mass of cement $(\mathrm{kg})$ per $\mathrm{m}^{3}$ of concrete

$\mathrm{S}_{\mathrm{c}}=$ specific gravity of cement

$\mathrm{M}_{\mathrm{sf}}, \mathrm{M}_{\mathrm{ca}}=$ total masses of the SF and CA $(\mathrm{kg})$ per $\mathrm{m}^{3}$ of concrete respectively
$\mathrm{S}_{\mathrm{ca}}, \mathrm{S}_{\mathrm{sf}}=$ specific gravities of saturated surface dry coarse aggregate and silica fume respectively, and $\mathrm{V}_{\mathrm{sol}}, \mathrm{V}_{\mathrm{ea}}=$ volume of solids in the super plasticizer and entrapped air (litres) per $\mathrm{m}^{3}$ of concrete respectively.

The fine aggregate content per unit volume of concrete is obtained by multiplying the absolute volume of fine aggregate and the specific gravity of the fine aggregate.

\section{Moisture adjustments}

The actual quantities of CA, FA and water content are calculated after allowing necessary corrections for water absorption and free (surface) moisture content of aggregates. The volume of water included in the liquid super plasticizer is calculated and subtracted from the initial mixing water.

\section{Unit mass of concrete}

The mass of concrete per unit volume is calculated by adding the masses of the concrete ingredients.

\section{Trail mix proportion}

Because of many assumptions underlying the foregoing theoretical calculations, the trial mix proportions must be checked. If necessary, the mix proportion should be modified to meet the desired workability and strength criteria, by adjusting the percentage replacement of cement by SF, percentage dosage of super plasticizer solid content of binder, air content and unit weight by means of laboratory trial batches to optimize the mix proportion. Fresh concrete should be tested for workability, unit weight and air content. Specimens of hardened concrete should be tested at the specified age.

\subsection{Mixture proportions and casting of specimens:}

Mix proportions are arrived for M80 and M100 grades of concrete based on the above formulated mix design procedure by replacing $0,2.5,5,7.5,10,12.5 \& 15$ percent of the mass of cement by SF \& the material requirements per $\mathrm{m}^{3}$ of concrete are given in table 6 and 7 . The ingredients for various mixes are weighed and mixing was carried out using a drum type mixer and casting were done in steel moulds for concrete cubes $150 \mathrm{~mm}$ size, cylinders $150 \mathrm{~mm}$ x $300 \mathrm{~mm}$ and beams $100 \mathrm{~mm} \times 100 \mathrm{~mm} \times 500 \mathrm{~mm}$. Curing was done under water for various desired periods. 
International Journal of Trend in Scientific Research and Development (IJTSRD) ISSN: 2456-6470

Table 6 Details of HPC trial mixes for M80 grade

\begin{tabular}{|c|c|c|c|c|c|c|c|c|}
\hline Mix designation & $\begin{array}{c}\text { SF } \\
(\%)\end{array}$ & $\begin{array}{c}\text { w/b } \\
\text { ratio }\end{array}$ & $\begin{array}{c}\text { Cement } \\
(\mathbf{K g})\end{array}$ & $\begin{array}{c}\text { SF } \\
(\mathrm{Kg})\end{array}$ & $\begin{array}{c}\text { FA } \\
(\mathrm{Kg})\end{array}$ & $\begin{array}{c}\text { CA } \\
(\mathrm{Kg})\end{array}$ & $\begin{array}{c}\text { Super plasti } \\
\text { cizer (lit) }\end{array}$ & $\begin{array}{c}\text { Water } \\
\text { (lit) }\end{array}$ \\
\hline C1 & 0 & 0.285 & 509.00 & 0 & 764.04 & 1070 & 12.52 & 140.84 \\
\hline C2 & 2.5 & 0.285 & 496.28 & 12.73 & 759.50 & 1070 & 12.52 & 140.84 \\
\hline C3 & 5 & 0.285 & 483.55 & 25.45 & 755.00 & 1070 & 12.52 & 140.84 \\
\hline C4 & 7.5 & 0.285 & 470.83 & 38.18 & 750.44 & 1070 & 12.52 & 140.84 \\
\hline C5 & 10 & 0.285 & 458.10 & 50.90 & 745.88 & 1070 & 12.52 & 140.84 \\
\hline C6 & 12.5 & 0.285 & 445.38 & 63.63 & 741.34 & 1070 & 12.52 & 140.84 \\
\hline C7 & 15 & 0.285 & 432.65 & 76.35 & 736.82 & 1070 & 12.52 & 140.84 \\
\hline
\end{tabular}

Table 7 Details of HPC trial mixes for M100 grade

\begin{tabular}{|c|c|c|c|c|c|c|c|c|}
\hline Mix designation & $\begin{array}{c}\text { SF } \\
(\%)\end{array}$ & $\begin{array}{c}\text { w/b } \\
\text { ratio }\end{array}$ & $\begin{array}{c}\text { Cement } \\
(\mathbf{K g})\end{array}$ & $\begin{array}{c}\text { SF } \\
(\mathrm{Kg})\end{array}$ & $\begin{array}{c}\text { FA } \\
(\mathrm{Kg})\end{array}$ & $\begin{array}{c}\text { CA } \\
(\mathrm{Kg})\end{array}$ & $\begin{array}{c}\text { Super plasti } \\
\text { ciner (lit) }\end{array}$ & $\begin{array}{c}\text { Water } \\
\text { (lit) }\end{array}$ \\
\hline C11 & 0 & 0.25 & 580.0 & 0 & 705 & 1070 & 14.26 & 139.56 \\
\hline $\mathrm{C} 12$ & 2.5 & 0.25 & 565.5 & 14.5 & 700 & 1070 & 14.26 & 139.56 \\
\hline $\mathrm{C} 13$ & 5 & 0.25 & 551.0 & 29.0 & 694 & 1070 & 14.26 & 139.56 \\
\hline $\mathrm{C} 14$ & 7.5 & 0.25 & 536.5 & 43.5 & 689 & 1070 & 14.26 & 139.56 \\
\hline $\mathrm{C} 15$ & 10 & 0.25 & 522.0 & 58.0 & 684 & 1070 & 14.26 & 139.56 \\
\hline $\mathrm{C} 16$ & 12.5 & 0.25 & 507.5 & 72.5 & 679 & 1070 & 14.26 & 139.56 \\
\hline $\mathrm{C} 17$ & 15 & 0.25 & 493.0 & 87.0 & 674 & 1070 & 14.26 & 139.56 \\
\hline
\end{tabular}

\section{TESTS ON FRESH AND HARDENED CONCRETE}

Workability tests such as Slump test, Compaction Factor test and Vee-Bee consistometer test were carried out for fresh concrete as per BIS specifications, keeping the dosage of super plasticizer as constant at $3 \%$ by weight of binder. For hardened concrete, cube compression strength test on $150 \mathrm{~mm}$ size cubes at the age of 1 day, 3 days, 7 days, 14 days, 28 days \& 56 days of curing were carried out using $3000 \mathrm{KN}$ capacity compression testing machine as per BIS : 516-1959. Also compression strength and split tensile strength tests on $150 \mathrm{~mm}$ x $300 \mathrm{~mm}$ cylinders and flexure test on $100 \mathrm{~mm}$ x $100 \mathrm{~mm}$ x $500 \mathrm{~mm}$ beams were carried out on 28 days cured specimens as per BIS specifications. The stress - strain graph for HPC is obtained using compressor meter fitted to cylinders during cylinder compressive strength test. UPV measurements were taken using NDT method on $150 \mathrm{~mm}$ size cubes for assessing the quality of concrete as per BIS : 13311 (Part 1) - 1992.

\section{RESULTS AND DISCUSSION}

Tests on fresh concrete

The test results of workability are listed in table 8 and 9 and also shown in figures $2,3 \& 4$. It was observed that the workability of concrete decreased as the percentage of SF content was increased.
Tests on hardened concrete

The results of cube compression strength, cylinder compression strength, spilt tensile strength, flexural strength and Modulus of Elasticity are also listed in table 8 and 9.

The optimum percentage of cement replacement by SF is $10 \%$ for the above tests for M80 and M100 grades of concrete. This may be due to the fact that the increase of strength characteristics in concrete is due to the pozzolanic reaction and filler effects of SF. The variations of average compressive strengths with respect to \% of SF at different ages are shown in figures $5 \& 6$. The ratio of cylinder to cube compression strength was found to be 0.81 . The flexure strengths obtained experimentally are higher than the value calculated by the expression $0.7 \square \mathrm{f}_{\mathrm{ck}}$ as per BIS: 456-2000. The variation of Modulus of Elasticity values with respect to \% of SF at 28 days for M80 \& M100 grades of concrete are shown in figure 7. The stress - strain curve at 28 days for M80 grade of concrete is shown in figure 8 , for $10 \% \mathrm{SF}$ content which is found to be optimum for Modulus of Elasticity values also. The Modulus of Elasticity achieved was $3.97 \mathrm{GPa}$ and 4.15 GPa for M80 M100 grades of concrete respectively at age of 28 days curing. The values are comparatively lower than the values calculated by the expression $5000 \square \mathrm{f}_{\mathrm{ck}}$ as per 
International Journal of Trend in Scientific Research and Development (IJTSRD) ISSN: 2456-6470 BIS: 456-2000. The UPV results of NDT are shown in concrete is excellent. table 10. The velocities prove that the quality of

Table 8 Properties of HPC mixes for M80 grade

\begin{tabular}{|c|c|c|c|c|c|c|c|}
\hline PROPERTIES & $\mathrm{C} 1$ & $\mathrm{C} 2$ & C3 & C4 & C5 & C6 & C7 \\
\hline Silica Fume (\%) & 0 & 2.5 & 5 & 7.5 & 10 & 12.5 & 15 \\
\hline \multicolumn{8}{|c|}{ Cube compressive strength (MPa), } \\
\hline 1day & 24.00 & 29.78 & 32.44 & 33.33 & 35.56 & 34.99 & 34.10 \\
\hline 3days & 39.11 & 44.44 & 44.89 & 50.22 & 55.11 & 49.48 & 48.89 \\
\hline 7days & 52.44 & 59.23 & 65.33 & 66.22 & 69.48 & 65.34 & 62.37 \\
\hline 14days & 59.26 & 65.63 & 67.56 & 72.00 & 78.67 & 74.37 & 73.33 \\
\hline 28days & 67.11 & 75.56 & 76.44 & 83.11 & 90.22 & 85.04 & 82.22 \\
\hline 56days & 75.32 & 84.65 & 86.30 & 94.22 & 101.33 & 95.44 & 92.11 \\
\hline Cylinder compressive strength (MPa), 28days & 52.97 & 59.98 & 61.00 & 66.04 & 71.87 & 65.53 & 65.08 \\
\hline Split tensile strength (Mpa), 28 days & 4.95 & 5.16 & 5.31 & 5.66 & 5.94 & 5.38 & 5.31 \\
\hline Flexural strength (Mpa), 28 days & 7.40 & 7.70 & 8.20 & 8.80 & 9.50 & 9.10 & 8.90 \\
\hline $\begin{array}{c}\text { Elastic modulus } \\
\text { (Gpa), 28days }\end{array}$ & 30.9 & 35.8 & 36.5 & 37.9 & 39.7 & 37.7 & 36.7 \\
\hline Slump (mm) & 52 & 46 & 45 & 41 & 37 & 22 & 15 \\
\hline Compaction Factor & 0.95 & 0.93 & 0.92 & 0.88 & 0.85 & 0.80 & 0.79 \\
\hline Vee-Bee degrees (secs) f Trend & 13 & $\mathrm{C} 14 /$ & 15 & 17 & 18 & 27 & 35 \\
\hline
\end{tabular}

Table 9 Properties of HPC mixes for M100 grade

\begin{tabular}{|c|c|c|c|c|c|c|c|}
\hline Properties & C11 & $\mathrm{C} 12$ & C13 & C14 & C15 & C16 & $\mathrm{C} 17$ \\
\hline Silica Fume $(\%)$ & 0 & 2.5 & 5 & 7.5 & 10 & 12.5 & 15 \\
\hline \multicolumn{8}{|c|}{ Cube compressive strength (MPa), } \\
\hline 1day & 28.59 & 34.37 & 36.00 & 39.41 & 44.74 & 44.59 & 41.19 \\
\hline 3days & 45.78 & 52.74 & 52.89 & 59.56 & 67.11 & 62.07 & 60.89 \\
\hline 7days & 62.37 & 68.74 & 73.63 & 80.15 & 84.75 & 80.15 & 78.07 \\
\hline 14days & 71.41 & 76.88 & 80.88 & 85.04 & 97.19 & 93.33 & 92.00 \\
\hline 28days & 83.11 & 89.04 & 93.89 & 100.80 & 110.66 & 105.33 & 102.67 \\
\hline 56days & 91.68 & 98.40 & 103.2 & 110.75 & 122.10 & 114.23 & 111.75 \\
\hline Cylinder compressive strength (MPa), 28days & 65.64 & 69.43 & 74.92 & 80.70 & 89.64 & 83.75 & 82.62 \\
\hline $\begin{array}{c}\text { Split tensile strength } \\
(\mathrm{MPa}), 28 \text { days }\end{array}$ & 5.81 & 6.41 & 6.89 & 7.16 & 7.53 & 7.41 & 7.31 \\
\hline $\begin{array}{l}\text { Flexural strength } \\
(\mathrm{MPa}), 28 \text { days }\end{array}$ & 8.60 & 9.00 & 9.40 & 9.60 & 10.40 & 9.80 & 9.40 \\
\hline $\begin{array}{c}\text { Elastic modulus } \\
(\mathrm{GPa}), 28 \text { days }\end{array}$ & 38.0 & 39.0 & 39.5 & 41.4 & 41.5 & 40.8 & 40.9 \\
\hline Slump (mm) & 30 & 28 & 27 & 25 & 25 & 18 & 15 \\
\hline Compaction Factor & 0.86 & 0.85 & 0.83 & 0.82 & 0.81 & 0.78 & 0.75 \\
\hline Vee-Bee degrees (secs) & 15 & 17 & 18 & 18 & 20 & 55 & 64 \\
\hline
\end{tabular}


International Journal of Trend in Scientific Research and Development (IJTSRD) ISSN: 2456-6470

Table 10 Results of Ultrasonic pulse Velocity of cubes at 28days

\begin{tabular}{|c|c|c|c|c|c|}
\hline $\begin{array}{c}\text { Mix } \\
\text { designation }\end{array}$ & $\begin{array}{c}\text { SF } \\
(\%)\end{array}$ & $\begin{array}{c}\text { Distance } \\
\text { traveled } \\
(\mathbf{m})\end{array}$ & $\begin{array}{c}\text { Time taken to travel }(\mathbf{t}) \\
\left(\mathbf{x} \mathbf{1 0}^{-6} \mathbf{s e c}\right)\end{array}$ & $\begin{array}{c}\text { Pulse } \\
\text { velocity } \\
(\mathbf{m} / \mathbf{s e c})\end{array}$ & $\begin{array}{c}\text { Quality of concrete } \\
\text { specimen }\end{array}$ \\
\hline $\mathrm{C} 1$ & 0 & 0.15 & 27.53 & 5448.60 & Excellent \\
\hline $\mathrm{C} 2$ & 2.5 & 0.15 & 27.02 & 5551.44 & Excellent \\
\hline C3 & 5.0 & 0.15 & 26.34 & 5694.76 & Excellent \\
\hline C4 & 7.5 & 0.15 & 25.65 & 5847.95 & Excellent \\
\hline C5 & 10.0 & 0.15 & 25.01 & 5997.60 & Excellent \\
\hline C6 & 12.5 & 0.15 & 25.42 & 5900.87 & Excellent \\
\hline C7 & 15.0 & 0.15 & 26.20 & 5725.19 & Excellent \\
\hline C11 & 0 & 0.15 & 26.36 & 5689.11 & Excellent \\
\hline C12 & 2.5 & 0.15 & 25.85 & 5802.34 & Excellent \\
\hline C13 & 5.0 & 0.15 & 25.46 & 5890.05 & Excellent \\
\hline C14 & 7.5 & 0.15 & 24.90 & 6023.97 & Excellent \\
\hline C15 & 10.0 & 0.15 & 24.05 & 6237.58 & Excellent \\
\hline C16 & 12.5 & 0.15 & 24.33 & 6164.00 & 5 \\
\hline C17 & 15.0 & 0.15 & 25.33 & 5921.26 & Excellent \\
\hline
\end{tabular}

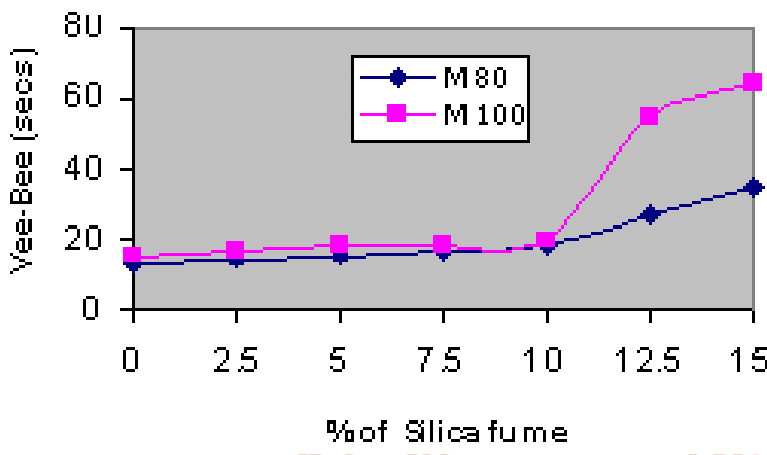

Figure 2 Workability through slump values

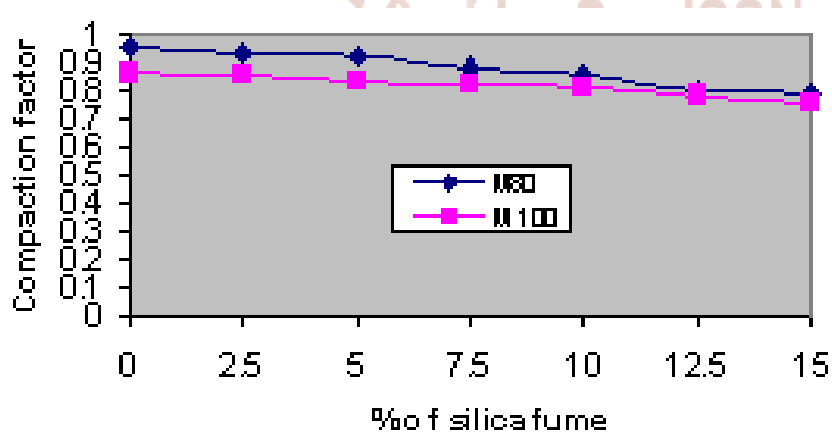

Figure 3 Workability through compaction factor values

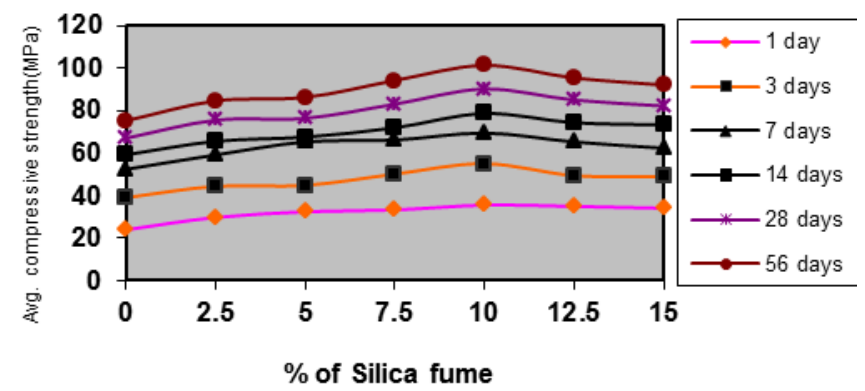

Figure 4 Average compare strength of silica fume

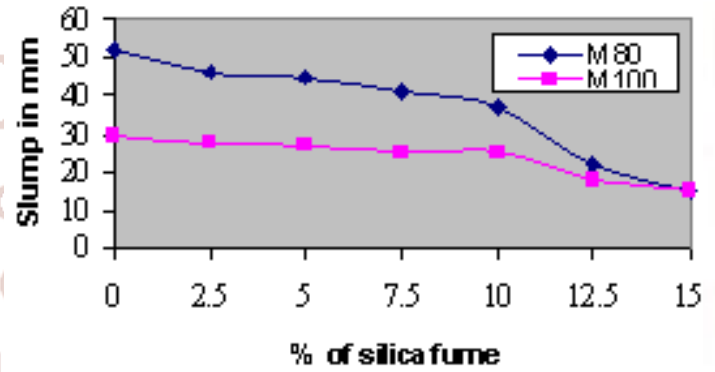

Figure 5 Variation of average compressive strength with respect to \% of SF at different ages (M80)

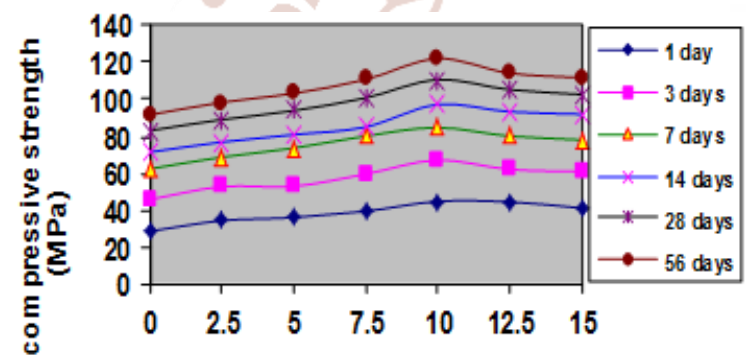

Figure: 6 variation of mpa and the sf

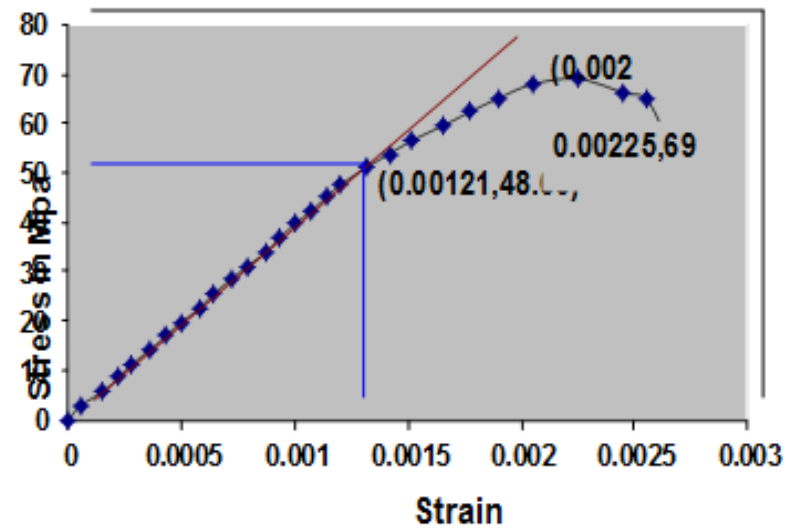

Figure 8: variation of stress and strain 


\section{CONCLUSIONS}

Based on the investigations carried out on HPC mixes, the following conclusions are drawn.

1. A simplified mix design procedure for HPC using SF and super plasticizer is formulated by combining BIS \& ACI code methods of mix design and available literatures on HPC.

2. The optimum percentage of cement replacement by SF is $10 \%$ for achieving maximum compressive, split tensile and flexural strengths and Elastic modulus.

3. The 7 days to 28 days compressive strength ratio of HPC is $0.75-0.80$.

4. The BIS: 456-2000 code underestimates the flexural strength and over estimates the Modulus of Elasticity for HPC.

5. Use of SF in concrete reduces the workability.

6. The compression failure pattern of concrete is due to crushing of coarse aggregate and not due to bond failure.

\section{ACKNOWLEDGEMENT}

The authors also express their heartfelt thanks to the Ramakrishna M Vidyalaya Management and the SRK Vidyalaya Polytechnic College, Swamiji's for having facilitated to present this paper. The author also grateful to the faculty members for their kind suggestions in bringing out this paper.

\section{REFERENCES}

1. NEVILLE (2000), "Properties of concrete", $4^{\text {th }}$ and final edition, Pearson Education Asia Pte. Ltd, England.

2. METHA \& MONTERIO (1999),"Concrete: microstructure, properties and materials", Indian edition, Indian Concrete Institute, Chennai.

3. NAWY (2001). "Fundamentals of high performance concrete", $2^{\text {nd }}$ edition, John Wiley \& Sons.Inc., New York.

4. SHAH \& AHMAD (1994), "High performance concretes and applications", Edward Arnold, London.

5. RIXOM \& MAILVAGANAM (1996), "Chemical Admixtures for concrete", $2^{\text {nd }}$ edition, E \& F. N SPON, London.

6. JOSHI (2001), "Evolution of HPC mixes containing silica fume," The Indian Concrete Journal, October 2001, Vol. 75, No.10, pp 627633.
7. BASU (2001), "NPP Containment structures: Indian experience in silica fume-based HPC", The Indian Concrete Journal, October 2001, Vol.75, No10, pp656-664.

8. AMIT MITTAL \& BASU (1999), "Development of HPC for PC dome of NPP, Kaiga", The Indian Concrete Journal, September 1999, Vol.73, No.9, pp548-556.

9. AMIT MITTAL \& KAMATH (1999), "Properties of HPC for PC dome of NPP, Kaiga", The Indian Concrete Journal, September 1999, Vol.73, No.9, pp 561-568.

10. CHINNAPPA (2001), "High Performance Concrete", Proceedings of the advanced in concrete technology with emphasis on HPC, held at Pondicherry, pp 185-194.

11. RAJAMANE (2000), "High Performance Concrete Mix Proportioning", advanced course on HP materials and Methodologies for construction and Rehabilitation of concrete structures, SERC, Chennai.

12. JAGADISH (2001), "High Performance concrete", proceedings of National seminar on" Waver of the Future, Civil Engineering in $21^{\text {st }}$ century," 15-16 June 2001, Association of Consulting Civil Engineers (India), Bangalore, pp 72-90.

13. SHIGIHALLI \& MANJUNATH (2002), High Strength Concrete containing silica fume", National Seminar on "Advances in concrete \& concrete structures", The Institution of Engineers (India), Belgaum.

14. WANG \& READ (1999), "Trials of grade 100 high-strength concrete", Magazine of Concrete Research, 51, No.6, Dec., pp 409-414.

15. BASU (2001), "High Performance Concrete: Mechanism and Application", ICI Journal, AprilJune 2001, pp15-26.

16. IAN BURNETT (1991), "Silica Fume Concrete in Melbourne, Australia", Concrete International, August 1991, pp 18-24.

17. FRANCQIS DE LARRARD \& THIERRY SEDRAN (2002), "Mixture - proportioning of high performance concrete", Cement and Concrete Research, 32 (2002), pp 1699-1704. 
18. IS: 10262-1982, "Recommended guidelines for concrete mix design", Bureau of Indian Standards, New Delhi.

19. SP: 23-1982, "Hand book on concrete mixes", Bureau of Indian Standards, New Delhi.

20. IS 13311 (Part1): 1992, "Non-Destructive testing of concrete- Methods of Test", Bureau of Indian Standards, New Delhi.

21. IS: 516-1959, "Methods of tests for strength of concrete", Bureau of Indian Standards, New Delhi.

22. IS: 9103:1999, “Concrete Admixtures specification", Bureau of Indian Standards, New Delhi.

23. IS: 5816-1970, "Method of test for splitting tensile strength of concrete cylinders", Bureau of Indian Standards, New Delhi.

24. IS: 1199-1959, "Methods of sampling and analysis of concrete", Bureau of Indian Standards, New Delhi.
25. IS: 383-1970, "Specification for coarse and fine aggregate from natural sources for concrete, Bureau of Indian Standards, New Delhi.

26. IS: 2386 (Part III) - 1963, "Methods of test for aggregates for concrete" Bureau of Indian Standards, New Delhi.

27. IS 12269: 1987, "Specification for 53 grade ordinary Portland cement", Bureau of Indian Standards, New Delhi.

28. IS 456:2000, "Plain and Reinforced Concrete Code of practice", $4^{\text {th }}$ Edition, Bureau of Indian Standards, New Delhi

29. AITCIN (1998), "High - Performance concrete", $1^{\text {st }}$ edition, E\& FN SPON, London.

30. KRISHNARAJU (1998), "Design of concrete mixes", $3^{\text {rd }}$ edition, CBS Publishers \& Distributors, New Delhi.

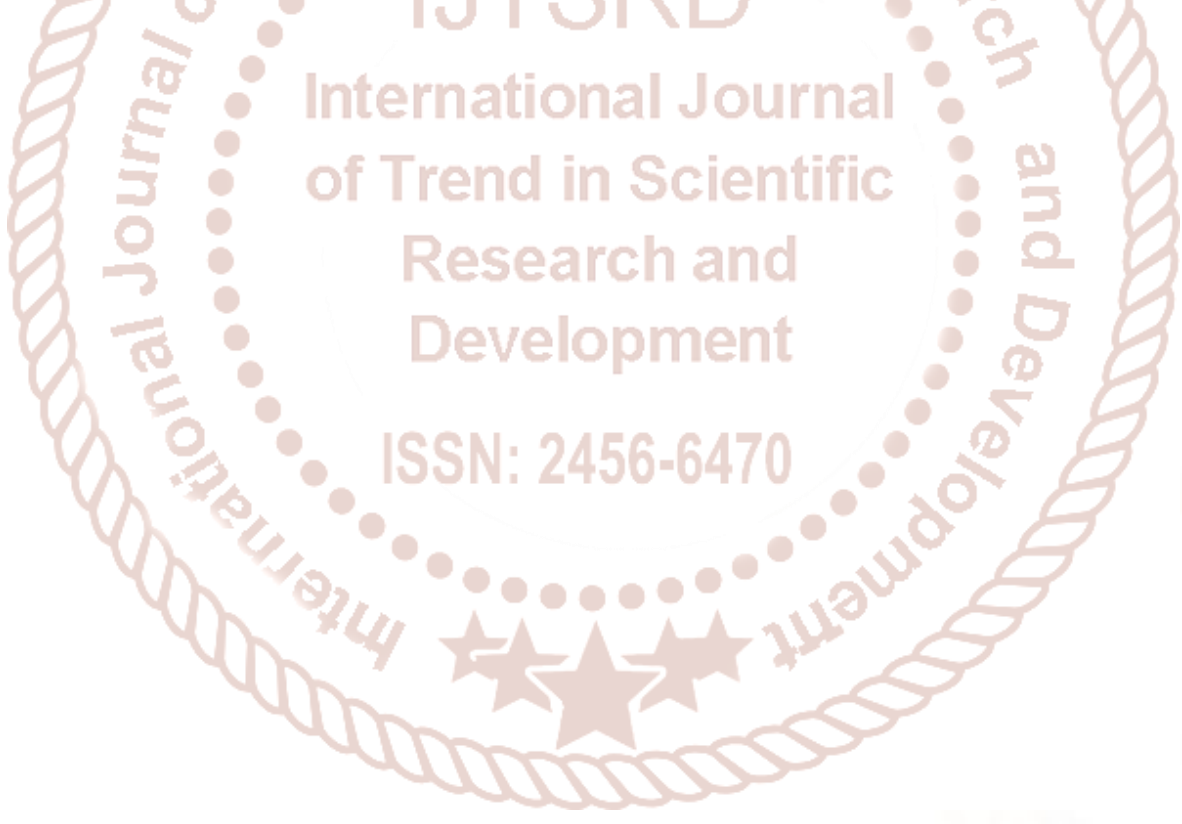

